\title{
Osteological Development of the Larvae and Juvenile of Luciogobius grandis (Pisces: Gobiidae)
}

\author{
Seong-Min Yun ${ }^{1}$, Jae-Min Park², and ${ }^{\dagger}$ Kyeong-Ho Han ${ }^{3}$ \\ ${ }^{1}$ Research Center for Freshwater Fishes, Uljin 36332, Korea \\ ${ }^{2}$ Native Fish Business Center, Uiseong 37366, Korea \\ ${ }^{3}$ Dept. of Aquaculture, Chonnam National University, Yeosu 59626, Korea
}

Received: April 21, 2020

Revised: April 28, 2020

Accepted: May 8, 2020

\section{Corresponding author Kyeong-Ho Han \\ Dept. of Aquaculture, \\ Chonnam National University, \\ Yeosu 59626, Korea. \\ Tel: +82-61-659-7163 \\ Fax: +82-61-659-7169 \\ E-mail:aqua05@jnu.ac.kr}

Copyright $\odot 2020$ The Korean Society of Developmental Biology.

This is an Open Access article distributed under the terms of the Creative Commons Attribution Non-Commercial License (http://creativecommons.org/licenses/ by-nc/4.0/) which permits unrestricted non-commercial use, distribution, and reproduction in any medium, provided the original work is properly cited.

ORCID

Seong Min Yun

https://orcid.org/0000-0001-8167-3001 Jae Min Park

https://orcid.org/0000-0001-6398-1748 Kyeong Ho Han

https://orcid.org/0000-0001-5918-3196

\section{Conflict of interests}

The authors declare no potential conflict of interest.

Acknowledgements

Not applicable.

Authors' contributions

Conceptualization: Yun SM.

Data curation: Yun SM.

Formal analysis: Yun SM.

Methodology:Yun SM.

Software:Yun SM, Park JM.

Validation: Han KH.

Investigation: Yun SM, Han KH.

Writing - original draft: Yun SM, Park JM.

Writing - review \& editing: Yun SM, Park JM.

\begin{abstract}
This study is intended to be used as the basic material for the taxonomic research by observing the stages of skeletal development of Luciogobius grandis larvae compared to the skeletal development patterns of the same fish family of Gobiidae. 3 days after hatching $(\mathrm{DAH})$, the preflexion larvae was $4.01 \pm 0.11 \mathrm{~mm}(n=5)$ in average total length $(T L)$ and the frontal began to ossify in the skull. $17 \mathrm{DAH}$, the advanced postflexion larvae was $5.37 \pm 0.05$ $\mathrm{mm}(\mathrm{n}=5)$ in average TL the supraoccipital and epiotic were ossified in the cranial bone. 36 $\mathrm{DAH}$, the juvenile was $12.2 \pm 0.20 \mathrm{~mm}(\mathrm{n}=5)$ in average TL and the urohyal was ossified in the hyoid arch. In addition to one hypural bone being ossified, the first, second, third and fourth were combined and were made three bone fragments and then, the bone ossification of all skeletons was completed.
\end{abstract}

Keywords: Gobiidae, Larvae, Luciogobius grandis, Osteological, Skeleton

\section{INTRODUCTION}

The fish family Gobiidae are known as about 1,975 species in 275 genera around the world (Nelson et al., 2016), and about 76 species in 39 genera are reported in Korea (NIBR, 2017). Luciogobius grandis is a fish belonging to the family Perciformes Gobiidae, and is known to be distributed in the coastal and intertidal zone of the East and South Seas of Korea. (Kim et al., 2005).

The characteristics of osteological development of larvae is essential to detect and eliminate skeletal abnormalities occurring in early breeding in the process of seed production (Koumoundouros et al., 1997a, b), and, providing systematic basic traits of the young stage, the researches in this area are active (Mook, 1977; Potthoff et al., 1987, 1988; Potthoff \& Tellock, 1993; Liu, 2001; Sfakianakis et al., 2004; Çoban et al., 2009).

The studies on L. grandis have done with the egg development and the larvae morphology development (Yun et al., 2008), and the studies on the skeleton of the fish family Gobiidae are Chaenogobius laevis (Kim \& Han, 1989), Periophthalmus cantonensis (Lee, 1990), L. guttatus (Kim et al., 1992), Tridentiger trigonocephalus (Han et al., 2018), T. obscurus (Hwang et al., 2018). The fish family Gobiidae is difficult to classify its species because there are species that have the same habitats or are similar externally. L. grandis is very similar externally to L. guttatus and the taxonomic studies are 
Ethics approval

This article does not require IRB/IACUC approval because there are no human and animal participants. needed to identify differences between the two species. Therefore, this study is intended to be used as the basic material for the taxonomic research, as observing the stages of skeletal development of L. grandis larvae by the stages of growth, and comparing and examining the skeletal development patterns of the same fish family of Gobiidae.

\section{MATERIALS AND METHODS}

\section{Collection and species identification}

The samples used in the study were collected from individuals showing allomothering and transported to the laboratory at the spawning site for spawned eggs and species identification under a rock in a small river connected to the sea located in Ocheon-dong, Yeosu-si, Jeollanam-do Korea in May 2006. It followed Kim et al. (2005) for the species identification.

\section{Fertilized egg and rearling larvae}

The fertilized eggs attached to the rock was housed in a square tank $(45 \times 30 \times 20 \mathrm{~cm})$, and was gently aerated by aeration after medicine bathing with $5 \%$ neutral formalin. It was maintained the breeding water temperature at $18^{\circ} \mathrm{C}-21^{\circ} \mathrm{C}$ (average $19.5 \pm 1.5^{\circ} \mathrm{C}$ ), and salinity at $30-33$ psu (average $31.5 \pm 1.5 \mathrm{psu}$ ), from the salt concentration (YSI 556) was measured using a water quality meter. 21 days after hatching (DAH), it was fed Brachionus rotundiformis to the hatched larvae after completing yolk absorption, and fed 1-2 Artemia sp. nauplius per mL. From $42 \mathrm{DAH}$, feeding was carried out while mixing and feeding the microdiet particles (Dry feed, Jeilfeed, haman, Korea).

\section{Skeleton staining}

In order to observe the skeletal development of larvae, 5 specimens were collected at intervals of 3 to 10 days from just immediately after hatching to 51 days and measured their sizes to $0.01 \mathrm{~mm}$ with a profile projector (V-12B, Nikon, Tokyo, Japan), and, after fixing them in 5\% neutral formalin, the tibia was stained according to the staining method of Kawamura \& Hosoya (1991). The shape of the skeleton was sketched after observing with a anatomy microscope (NM-40, Nikon), and the name of each part of the skeleton was according to Kim et al. (1992).

\section{RESULTS}

\section{Species identification}

The head was a flat shape with a opercle, the dorsal fin was located at the back from the center, and the caudal fin edges were rounded. The meristic characters were 16 dorsal fins and 16 anal fins, and the lateral line scales were not observed. In the pectoral fin, two or more separated fin-rays appeared, showing a difference from the similar species, Luciogobius guttatus identified as L. grandis (Kim et al., 2005).

\section{The osteological development of larvae and juvenile}

The skeleton of $L$. grandis larvae was divided into cranial, shoulder girdle, vertebrae, and coccyx, and the development process of the growth stage was shown in Figs. 1, 2; Tables 1-3. On the 3 $\mathrm{DAH}$, the preflexion larvae was $3.86-4.13 \mathrm{~mm}$ in total length (TL) (average $4.01 \pm 0.11 \mathrm{~mm}, \mathrm{n}=5$ ), and the frontal began to ossify in the skull, and the parasphenoid ossified across the eyeball. The premaxillary and maxillary of the upper jaw were ossified in the jaw bones with intake function and 


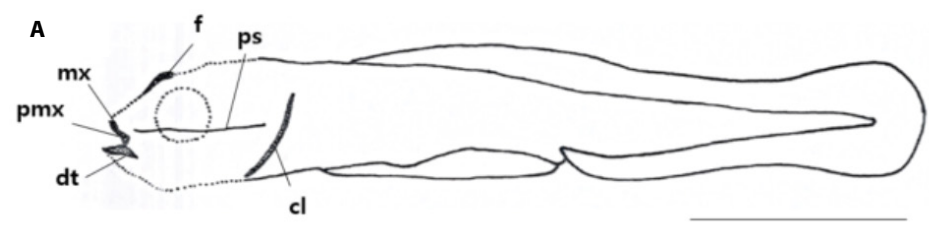

B

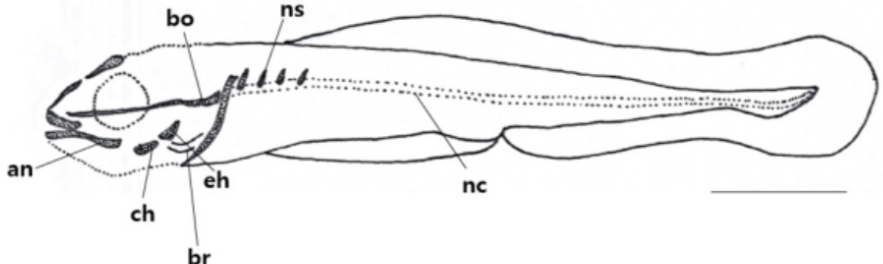

C

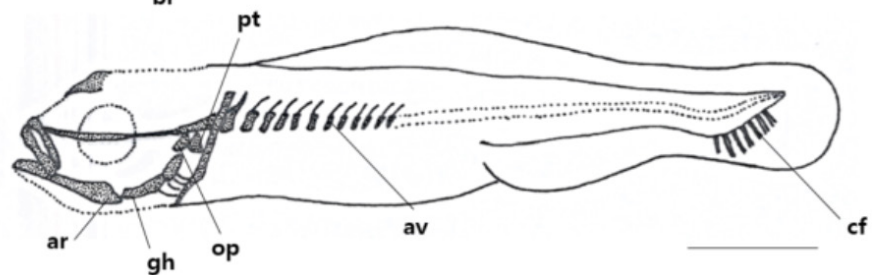

Fig. 1. Development stage of larvae skeleton in Luciogobius grandis. (A) 3 days after hatching (DAH) preflexion larvae, $4.01 \mathrm{~mm}$ in total length (TL), (B) $8 \mathrm{DAH}$ preflexion larvae, $4.87 \mathrm{~mm}$ in TL, (C) $11 \mathrm{DAH}$ preflexion larvae, $5.37 \mathrm{~mm}$ in TL. an, angular; ar, articular; av, abdominal vertebrae; br, branchiostegal; bo, basioccipital; cf, caudal fin; ch, ceratohyal; cl, clavicle; dt, dantary; eh, epihyal; f, frontal; gh, grosshyal; $\mathrm{mx}$, maxillary; nc, notochord; ns, neural spine; op, opercle; pmx, premaxillary; ps, parasphenoid; pt pterotic. Scale bars $=1.0 \mathrm{~mm}$.

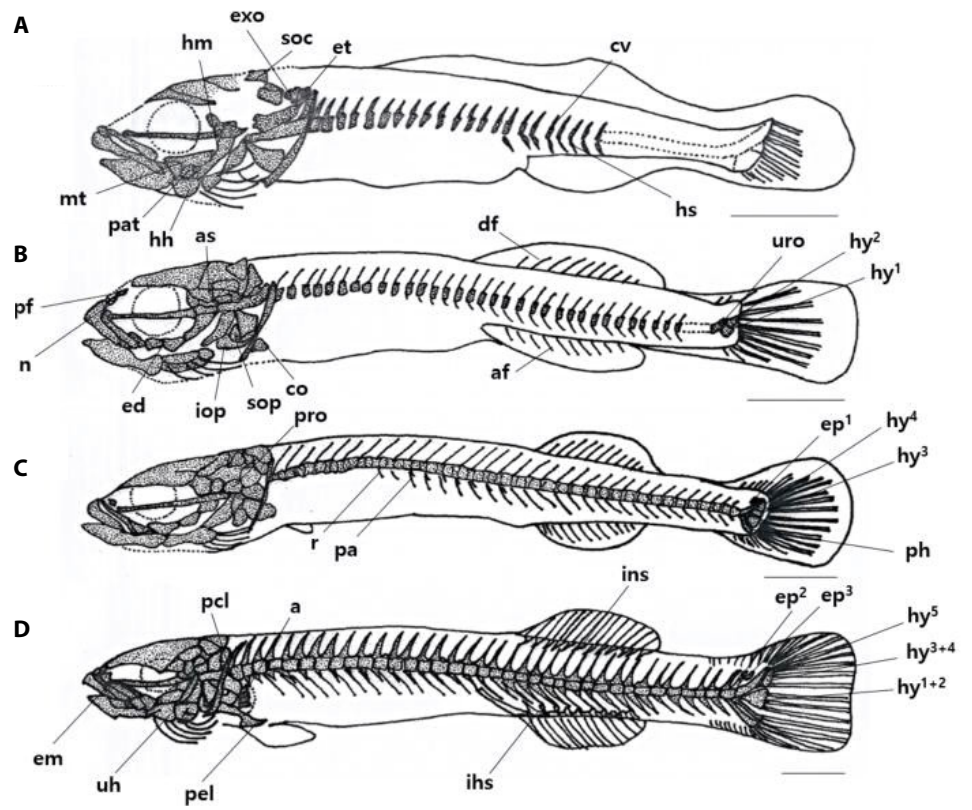

Fig. 2. Development stage of larvae and juvenile skeleton in Luciogobius grandis. (A) 17 days after hatching (DAH) postflexion larvae, $5.73 \mathrm{~mm}$ in total length (TL), (B) 21 DAH postflexion larvae, $7.04 \mathrm{~mm}$ in TL, (C) 29 DAH preflexion larvae, $11.4 \mathrm{~mm}$ in TL, (D) $36 \mathrm{DAH}$ juvenile, $12.2 \mathrm{~mm}$ in TL. a, actinost; af, anal fin; as, alisphenoid; co, coracoid; cv, caudal vertebrae; df, dorsal fin; ed, endopterygoid; em, ethmoid; ep, epural bone; et, epiotic; exo, exoccipital; hh, hypohyal; hm, hyomandibular; hs, hemal spine; hy, hypural bone; ins, interhemal spine; ins, interneural spine; iop, interopercle; mt, metapterygoid; $\mathrm{n}$, nasal; pa, parapophysis; pel, pelvic girdle; ph, parhypural bone; pat, parietal; pcl, postclavicle; pf, prefrontal; pro, prootic; r, rib; soc, supraoccipital; sop, subopercle; uh, urohyal; uro, urostyle. Scale bars $=1.0 \mathrm{~mm}$. 
Table 1. The development process of cranium and shoulder girdle of Luciogobius grandis

\begin{tabular}{|c|c|c|c|c|c|c|c|c|}
\hline & \multirow{2}{*}{ Variable } & \multicolumn{7}{|c|}{ Days after hatching (Average total length, $\mathrm{mm}$ ) } \\
\hline & & $3(4.01)$ & $8(4.87)$ & $11(5.37)$ & $17(5.73)$ & $21(7.04)$ & $29(11.4)$ & $36(12.2)$ \\
\hline \multirow{12}{*}{ Cranium } & Parasphenoid & & & & & & & \\
\hline & Basioccipital & & & & & & & \\
\hline & Exoccipital & & & & & & & \\
\hline & Frontal & & & & & & & \\
\hline & Parietal & & & & & & & \\
\hline & Epiotic & & & & & & & \\
\hline & Supraoccipital & & & & & & & \\
\hline & Nasal & & & & & & & \\
\hline & Alisphenoid & & & & & & & \\
\hline & Prootic & & & & & & & \\
\hline & Prefrontal & & & & & & & \\
\hline & Lateral ethmoid & & & & & & & \\
\hline \multirow{5}{*}{$\begin{array}{l}\text { Shoulder } \\
\text { girdle }\end{array}$} & Clavicle & & & & & & & \\
\hline & Coracoid & & & & & & & \\
\hline & Pelvic girdle & & & & & & & \\
\hline & Actinost & & & & & & & \\
\hline & Post clavicle & & & & & & & \\
\hline
\end{tabular}

Table 2. The development process of vertebrae and caudal skeleton of Luciogobius grandis

\begin{tabular}{|c|c|c|c|c|c|c|c|c|}
\hline & \multirow{2}{*}{ Variable } & \multicolumn{7}{|c|}{ Days after hatching (Average total length, $\mathrm{mm}$ ) } \\
\hline & & $3(4.01)$ & $8(4.87)$ & $11(5.37)$ & $17(5.73)$ & $21(7.04)$ & $29(11.4)$ & $36(12.2)$ \\
\hline \multirow{9}{*}{ Vertebrae } & Notochord & & & & & & & \\
\hline & $\begin{array}{l}\text { Abdominal } \\
\text { vertebrae }\end{array}$ & & & & & & & \\
\hline & Neural spine & & & & & & & \\
\hline & $\begin{array}{l}\text { Caudal } \\
\text { vertebrae }\end{array}$ & & & & & & & \\
\hline & Hemal spine & & & & & & & \\
\hline & Parapophysis & & & & & & & \\
\hline & Rib & & & & & & & \\
\hline & $\begin{array}{l}\text { Interneural } \\
\text { spine }\end{array}$ & & & & & & & \\
\hline & $\begin{array}{l}\text { Interhemal } \\
\text { spine }\end{array}$ & & & & & & & \\
\hline \multirow{9}{*}{$\begin{array}{l}\text { Caudal } \\
\text { skeleton }\end{array}$} & Urostyle & & & & & & & \\
\hline & Hypural bone & & & & & & & \\
\hline & $5^{\text {th }}$ & & & & & & & \\
\hline & $3^{\text {rd }}-4^{\text {th }}$ & & & & & & & \\
\hline & $1^{\text {st }}-2^{\text {nd }}$ & & & & & & & \\
\hline & Parhypural bone & & & & & & & \\
\hline & Epural bone & & & & & & & \\
\hline & $1^{\text {st }}$ & & & & & & & \\
\hline & $2^{\text {nd }}-3^{\text {rd }}$ & & & & & & & \\
\hline
\end{tabular}


Table 3. The development process of visceral skeleton of Luciogobius grandis

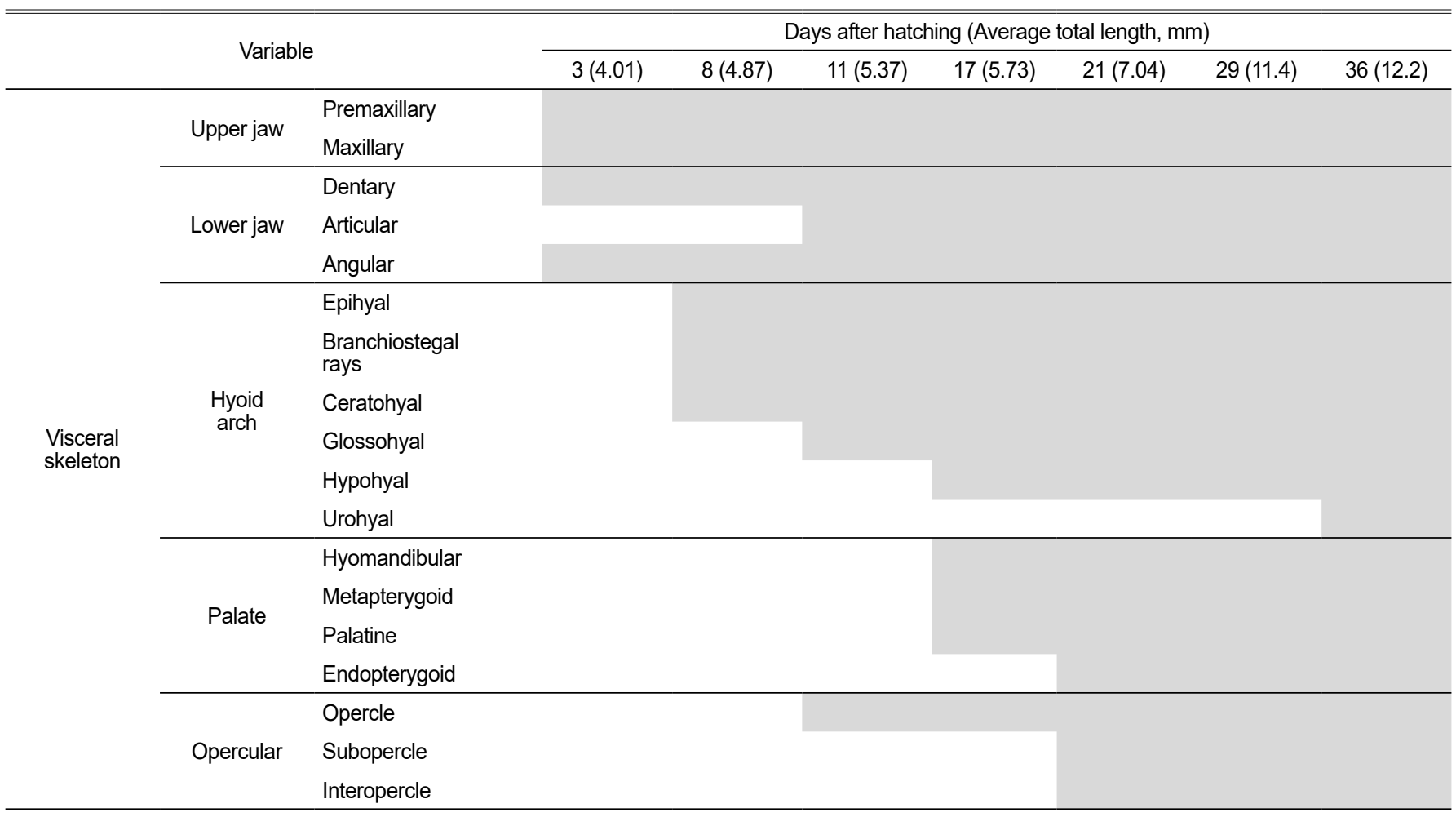

the dentary was ossified in the lower jaw. The clavicle was ossified in the shoulder girdle bone (Fig. $1 \mathrm{~A})$.

On the $8 \mathrm{DAH}$, the preflexion larvae was $4.77-4.95 \mathrm{~mm}$ in TL (average $4.01 \pm 0.11 \mathrm{~mm}, \mathrm{n}=5$ ), the basioccipital was ossified in the cranial bone, the angular was ossified in the palate and set in the dentary bone of the lower jaw. The epihyal and ceratohyal were ossified in the palatoglossal arch, and two branchiostegal rays began to ossify under the upper hyoid bone. The vertebrae that forming the central axis of the body was not ossified and consisted of notochord, and the neural spine began to ossify above the abdominal vertebrae (Fig. 1B).

On the $11 \mathrm{DAH}$, the advanced postflexion larvae was $5.30-5.44 \mathrm{~mm}$ in TL (average $5.37 \pm 0.05$ $\mathrm{mm}, \mathrm{n}=5$ ), the palatine was ossified in the cranial bone, the articular was ossified in the palate and set in the angular bone. The glossohyal was ossified in the palatoglossal arch, the opercle began to ossify in the branchial arch. The vertebrae which consisted of the spine began to develop as the abdominal bone ossified. The caudal fin rays at the distal end of the body began to develop (Fig. 1C).

On the $17 \mathrm{DAH}$, the advanced postflexion larvae was $5.62-5.85 \mathrm{~mm}$ in TL (average $5.37 \pm 0.05$ $\mathrm{mm}, \mathrm{n}=5$ ), the supraoccipital and epiotic were ossified in the cranial bone, the hyomandibular, metapterygoid, palatine were ossified in the palate, and the hypohyal was ossified in the palatoglossal arch. In the vertebrae, the caudal vertebrae began to ossify with the hemal spine as the abdominal bone was ossified with the nerve toward the tail. (Fig. 2A).

On the $21 \mathrm{DAH}$, the advanced postflexion larvae was $6.91-7.17 \mathrm{~mm}$ in TL (average $7.04 \pm 0.10$ $\mathrm{mm}, \mathrm{n}=5$ ), the prefrontal, alisphenoid, and nasal were ossified in the cranial bone, the endopterygoid was ossified in the palate, and the subopercle, interopercle were ossified under the opercle in the opercular.

The coracoid was ossified in the shoulder girdle bone, and the dorsal fin rays and anal fin rays 
developed as the primordial fin was divided into dorsal, anal, and tail fin. In the coccyx, the vertebral end was bent upward, and the urostyle began to ossify, and at the bottom, two hypural bones ossified (Fig. 2B).

On the $29 \mathrm{DAH}$, the advanced postflexion larvae was $11.2-11.8 \mathrm{~mm}$ in TL (average $11.4 \pm 0.24$ $\mathrm{mm}, \mathrm{n}=5$ ), the prootic was ossified in the cranial bone, and the rib and parapophysis were ossified under the abdominal vertebra. In the coccyx, 2 hypural bones were additionally ossified, the parhypural bone was ossified under the first hypural bone, and 1 epural bone was ossified between the neural spine and urostyle (Fig. 2C).

On the $36 \mathrm{DAH}$, the juvenile was $12.0-12.5 \mathrm{~mm}$ in TL (average $12.2 \pm 0.20 \mathrm{~mm}, \mathrm{n}=5$ ), the lateral ethmoid was ossified in the cranial bone, and the urohyal was ossified in the hyoid arch, and the pelvic girdle was ossified in the ventral.

The actinost and the post cleithrum were ossified in the shoulder girdle bone, and the interneural spine and the interhemal spine were ossified in the pterygiophore supporting the dorsal and anal fins. Two pural bones were additionally developed in the coccyx, and one hypural bone was ossified in addition, and then, the first, second, third, and fourth were combining and made of three bone fragments, and the bone ossification of all skeletons was completed (Fig. 2D).

\section{DISCUSSION}

The skeletal development of $L$. grandis was not observed just immediately after hatching. While growing, on the $3 \mathrm{DAH}$ when the average TL was $4.01 \mathrm{~mm}$, the frontal and the parasphenoid in the cranial bone began to ossify. In this period, as the yolk absorption was completed, the feeding function developed and the premaxillary, maxillary, and dentary were ossified. In addition, swimming ability developed as the clavicle of the shoulder girdle bone ossified. The skeletal development of T. trigonocephalus (Han et al., 2018), the same fish family Gobiidae, was began when the average TL was $4.44 \mathrm{~mm}$ on $7 \mathrm{DAH}$. The skeletal developments were began when $L$. guttatus (Kim et al., 1992) was $5.50 \mathrm{~mm}$ in TL on $11 \mathrm{DAH}$, when C. laevis (Kim \& Han, 1989) was $6.00 \mathrm{~mm}$ in TL on 9 DAH, and when T. obscurus (Hwang et al., 2018) was $3.62 \mathrm{~mm}$ in TL on $8 \mathrm{DAH}$.

The fish family Gobiidae has an egg yolk right after hatching, so it survives for a period of time without feeding, during this period, the mouth opens for feeding and the swimming ability develops, and it is known that the development of feeding function and the role of clavicle are related (Wagemans \& Vandewalle, 1999).

The shoulder girdle bone of $L$. grandis developed in the order of clavicle, coracoid, actinost, and post cleithrum when the average TL was $4.01 \mathrm{~mm}$ on $3 \mathrm{DAH}$, T. trigonocephalus (Han et al., 2018), a fish family Gobiidae, was ossified in the order of clavicle, coracoid, and actinost when the average TL of $4.44 \mathrm{~mm}$ on 7 DAH, and L. guttatus (Kim et al., 1992) ossified in the order of clavicle, coracoid, scapula, and actinost when the average TL was $5.50 \mathrm{~mm}$ on the $11 \mathrm{DAH}$. C. laevis (Kim $\&$ Han, 1989) ossified in the order of clavicle, scapula, and actinost when the average TL was 6.30 $\mathrm{mm}$ on 13 DAH, T. obscurus (Hwang et al., 2018) ossified in the order of clavicle, actinost, coracoid, and scapula on $13 \mathrm{DAH}$, as it showed a slight difference according to the order of ossification, but it was a relatively similar developmental pattern.

L. grandis was observed to have one pore formed in the scapula when the average TL was 12.2 $\mathrm{mm}$ on $36 \mathrm{DAH}$, mostly observed in the same fish family Gobiidae, and the formating pores in the scapula is known as a taxonomic trait that appears only in L. japonicus, but is considered a general trait observed in various fish (Han et al., 2018). 
Specifically, the number of vertebrae has been used as a taxonomical character (Yamada et al., 2009). Table 4 compares the number of vertebrae in fish of the genus Luciogobius. The vertebrae development of $L$. grandis began to abdominal vertebrae ossification from head to tail when it was $4.87 \mathrm{~mm}$ on the $8 \mathrm{DAH}$, after the neural spine ossified, and when the average TL is 5.37 $\mathrm{mm}$ on 11 DAH. T. trigonocephalus (Han et al., 2018), the same fish family Gobiidae, began to ossify abdominal vertebrae at an average TL of $5.02 \mathrm{~mm}$ on $10 \mathrm{DAH}$, and when L. guttatus had an average TL of $6.10 \mathrm{~mm}$ on $16 \mathrm{DAH}$, the neural spine was ossified simultaneously with the ossification of the abdominal vertebrae. In C. laevis (Kim \& Han, 1989), the abdominal vertebrae and caudal vertebrae ossified simultaneously at an average TL of $6.00 \mathrm{~mm}$ on 9 DAH. In T. obscurus (Hwang et al., 2018), the neural spine ossified after abdominal vertebrae ossification at $3.96 \mathrm{~mm}$ on the 10 DAH. L. grandis developed abdominal vertebrae after neural spine development, L. guttatus, $T$. trigonocephalus, and T. obscurus developed abdominal vertebrae and ossified neural spine, and hemal spine, and in C. laevis, abdominal vertebrae and caudal vertebrae were ossified at the same time, showing a difference from the order of development of $L$. grandis.

The stems of dorsal fin and anal fin of $L$. grandis developed simultaneously when the average TL was $7.04 \mathrm{~mm}$ on $21 \mathrm{DAH}$, T. trigonocephalus (Han et al., 2018), the same fish family, began to develop the dorsal fin stem after the posterior dorsal fin development when the average TL is 6.40 $\mathrm{mm}$ on $16 \mathrm{DAH}$, Mugilogobius abei (Kim \& Han, 1991) was when an average TL was $3.20 \mathrm{~mm}$ on $12 \mathrm{DAH}$, and T. obscurus (Hwang et al., 2018) began to develop stems on the dorsal and posterior fins on the back when the average TL was $7.99 \mathrm{~mm}$ on 28 DAH. C. laevis (Kim \& Han, 1989) began to develop the stem of dorsal fin and anal fin when the average TL was $7.05 \mathrm{~mm}$ on 17 DAH, and L. guttatus (Kim et al., 1992) began to develop the stem of dorsal fin and anal fin with an average TL of $6.10 \mathrm{~mm}$ on $16 \mathrm{DAH}$. L. grandis had the same structure as L. guttatus with one dorsal and anal fin respectively, and the development patterns of them were similar.

L. grandis developed the fin stem at the latest among the same fish family, and the same fish families, T. trigonocephalus, M. abei, C. laevis, and T. obscurus, showed differences from the fin development process of $L$. grandis because the dorsal fin was divided into the front and back. In addition, the dorsal fin developed from the rear to the front and was similar to the general development pattern of L. japonicus (Johnson, 1984; Faustino \& Power, 1999).

The pterygiophore development of $L$. grandis occurred after centrum development began, and

Table 4. Comparison of the number of vertebrae in fish of the genus Luciogobius

\begin{tabular}{lcc}
\hline \multicolumn{1}{c}{ Species } & Vertebrae number & Authors \\
\hline Luciogobius & $36-37$ & Present study \\
L. grandis (Yeosu, Korea) & $40-42$ & Yamada et al. (2009) \\
L. grandis (Shirahama, Japan) & $38-44$ & \\
L. elongatus & 50 & \\
L. adapel & $41-42$ & \\
L. platycephalus & $41-43$ & \\
L. parvulus & $35-39$ & \\
L. guttatus & 37 & \\
L. pallidus & $30-31$ & \\
L. albus & 36 & \\
L. dormitoris & 35 & \\
L. brevipterus & 33 & \\
L. martellii & & \\
\hline
\end{tabular}


this developmental pattern appeared in the same fish family Gobiidae, and the pterygiophore was fully formed after completed the development of fin stem. The developing pterygiophore when the development of vertebrae and fins has been completed appears to be related to increased propulsion in fish swimming (Lee et al., 2001).

The coccyx of L. grandis consisted of the urostyle, the pural bone, the hypural bone, and the parhypural bone, the urostyle began to ossify when the average TL was $7.04 \mathrm{~mm}$ on the $21 \mathrm{DAH}$, it began to ossify that T. trigonocephalus (Han et al., 2018) was when the average TL was $9.32 \mathrm{~mm}$ on the $28 \mathrm{DAH}$, L. guttatus (Kim et al., 1992) was when the average TL was $7.60 \mathrm{~mm}$ on the 25 DAH, C. laevis (Kim \& Han, 1989) was when the average TL was $7.25 \mathrm{~mm}$ on the $20 \mathrm{DAH}$, and T. obscurus (Hwang et al., 2018) was when the average TL was $7.99 \mathrm{~mm}$ on the $28 \mathrm{DAH}$, and $L$. grandis and T. trigonocephalus were similar in the period of urostyle and their TL.

The fusion of the hypural bone formed 3 hypural bones $(1+2,3+4,5)$ when the average TL was $12.2 \mathrm{~mm}$ on the $36 \mathrm{DAH}$. It showed the differences as T. trigonocephalus (Han et al., 2018) formed three hypural bones $(1+2,3+4,5)$, and C. laevis (Kim \& Han, 1989) and L. guttatus (Kim et al., 1992) formed two hypural bones $(1+2,3+4+5)$.

Thus, as the shape of hypural bone appeared diverse in the same fish family Gobiidae, it is considered to be significant as the basic data for systematic research. The differences in the skeletal development of the larvae of L. grandis and L. guttatus are that L. grandis showed the faster ossification of the first skeleton, and the abdominal vertebra of vertebra L. grandis ossified after ossification of the neural spine, but, in L. guttatus, vertebrae and neural spine were ossified simultaneously and showed the difference. It could be verified the two similar species have exomorphic difference through the results of this study as L. guttatus was fused into two bone fragments, while the hypural bone of $L$. grandis was fused into three. In the future, the study of the skeletal development of larvae is thought to be used as a very significant basic data for understanding species identification and skeletal characteristics of an adult fish, and it seems that more researches have to be carried out to characterize the classification and skeletal characteristics of the fish family Gobiidae.

\section{REFERENCES}

Çoban D, Suzer C, Kamaci HO, Saka Ş, Firat K (2009) Early osteological development of the fins in the hatchery-reared red porgy, Pagrus pagrus (L. 1758).J Appl Ichthyol 25:26-32.

Faustino M, Power DM (1999) Development of the pectoral, pelvic, dorsal and anal fins in cultured sea bream. J Fish Biol 54:1094-1110.

Han KH, Lee SH, Kim DY, Seo WII, Park JM (2018) Osteological development of the larvae and juvenile of chameleon goby, Tridentiger trigonocephalus. Korean J Ichthyol 30:137-143.

Hwang SY, Park JM, Lee SH, Han KH (2018) Osteological development of the larve and juvenile of trident goby, Tridentiger obscurus. Dev Reprod 22:205-212.

Johnson GD (1984) Percoidei: Development and relationship. In: Moser HG, Richards WJ, Cohen DM, Fahay MP, Kendall AW, Richardson SL (eds), Ontogeny and systematics of fishes. American Society of Ichthyologists and Herpetologists, Allen Press, Lawrence, KS, pp 464498.

Kawamura K, Hosoya K (1991) A moidifed double staining techinque marking a transparent fish skeletal. Bull Nat Res Inst Aquac 20:11-18.

Kim IS, Choi Y, Lee CL, Lee YJ, Kim BJ, Kim JH (2005) Illustrated Book of Korean Fishes. KyoHak, Seoul, Korea, pp 420-443. 
Kim YU, Han KH (1989) Early life history of the marine animals 1. Egg development, larvae and juveniles of Chaenogobius laevis (Steindachner). Bull Korean Fish Soc 22:317-331.

Kim YU, Han KH (1991) Early life history and spawning behavior of the gobiidae fish, Mugilogobius abei (Jordan et Snyder) reaerd in the laboratory. Korean J Ichthyol 3:1-10.

Kim YU, Han KH, Kang CB, Ryu JW (1992) Early life history and spawning behavior of the gobiid fish, Luciogobius guttatus Gill. Korean J Ichthyol 4:1-13.

Koumoundouros G, Gagliardi F, Divanach P, Boglione C, Cataudella S, Kentouri M (1997a) Normal and abnormal osteological development of caudal fin in Sparus aurata L. fry. Aquaculture 149:215-226.

Koumoundouros G, Oran G, Divanach P, Stefanakis S, Kentouri M (1997b) The opercular complex deformity in intensive gilthead sea bream (Sparus aurata L.) larviculture. Moment of apparition and description. Aquaculture 156:165-177.

Lee CL (1990) Osteological study of the mudhopper, Periothalmus cantonensis (Perciformes, Gobiidae) from Korea. Korean J Zool 33:402-410.

Lee SJ, Kim YU, Han KH (2001) Osteological development of larvae and juveniles of Hyporhamphus sajori (Teleostei: Hemiramphidae). Korean J Ichthyol 13:173-180.

Liu CH (2001) Early osteological development of the yellow tail Seriola dumerili (Pisces: Carangidae). Zool Stud 40:289-298.

Mook D (1977) Larval and osteological development of the sheepshead, Archosargus probatocephalus (Pisces: Sparidae). Copeia 1977:126-133.

Nelson JS, Grande TC, Wilson MVH (2016) Fishes of the World. 5th ed. John Wiley \& Sons, Hoboken, NJ, pp 329-333.

NIBR [National Institute of Biological Resources] (2017) National list of species of Korea. National institute of biological resources. Available from http://kbr.go.kr. accessed at May 19, 2020.

Potthoff T, Kelley S, Collins LA (1988) Osteological development of the red snapper, Lutjanus campechanus (Lutjanidae). Bull Mar Sci 43:1-40.

Potthoff T, Kelly S, Saksena V, Moe M, Young F (1987) Description of larval and juvenile damselfish Microspathodon chrysurus, Pomacentridae, and their osteological development. Bull Mar Sci 40:330-375.

Potthoff T, Tellock JA (1993) Osteological development of the snook, Centropomus undecimalis (Teleostei, Centropomidae). Bull Mar Sci 52:669-716.

Sfakianakis DG, Koumoundouros G, Divanach P, Kentouri M (2004) Osteological development of the vertebral column and of the fins in Pagellus erythrinus (L. 1758). Temperature effect on the developmental plasticity and morpho-anatomical abnormalities. Aquaculture 232:407-424 .

Wagemans F, Vandewalle P (1999) Development of the cartilaginous skull in Solea solea: Trends in pleuronectiforms. Ann Sci Nat 20:39-52.

Yamada T, Sugiyama T, Tamaki N, Kawakita A, Kato M (2009) Adaptive radiation of gobies in the interstitial habitats of gravel beaches accompanied by body elongation and excessive vertebral segmentation. BMC Evol Biol 9:1-14.

Yun SM, Han KH, Lee SH, Yim HS, Hwang JH, Yeon IH, Kim YC (2008) Embryonic and larvae development of nake-headed goby, Luciogobius grandis. Dev Reprod 12:133-139. 
